\title{
POLA LUKA PADA KASUS KECELAKAAN LALU LINTAS DI BLU RSU PROF. DR. R.D. KANDOU MANADO PERIODE 2010-2011
}

\author{
Zella Anggy Angela \\ Djemmy Ch. Tomuka \\ James Siwu

\begin{abstract}
Kandidat Skripsi Fakultas Kedokteran Universitas Sam Ratulangi Manado
Bagian Forensik Fakultas Kedokteran Univesitas Sam Ratulangi Manado

Email: zellaangela@yahoo.com
\end{abstract}

\begin{abstract}
Traffic accident still the one of the world's public health problems. The number of traffic accidents cases has increased each year. According to the report of Badan Pusat Statistik Republik Indonesia, in 2008 the number of the traffic accidents found 59.164 cases, in 2009 found 62.960 cases, and keep rose in 2010 found 66.488 cases. Every cases of traffic accidents cause the various of some injuries pattern. The distribution victims characteristics of the traffic accident particularly found in the productive age and dominated by male. This research aimed to know how the injuries pattern of accident traffic cases at BLU RSU Prof. Dr. R. D. Kandou Manado period 2010-2011. This research designed in retrospective descriptive. The result of this research found that has increased cases of traffic accident on period 2010-2011. This cases dominated by male, with the most of interval age included on 11-20 years and 21-30 years. The most number of traffic accident injuries was superficial injuries, with the most location of injuries was found on the head and the neck. Kind of traffic accident most found on the motorcycle driver case.
\end{abstract}

Key word: Injuries pattern of traffic accident.

Abstrak: Kecelakaan lalu lintas sampai saat ini masih merupakan salah satu masalah kesehatan masyarakat di seluruh dunia. Jumlah kasus kecelakaan lalu lintas dari tahun ke tahun terus meningkat. Menurut data Badan Pusat Statistik Republik Indonesia, pada tahun 2008 jumlah kasus kecelakaan lalu lintas terdapat 59.164 kasus, kemudian meningkat di tahun 2009 dengan jumlah 62.960 kasus, dan terus meningkat di tahun 2010 dengan jumlah 66.488 kasus kecelakaan lalu lintas. Setiap kasus kecelakaan lalu lintas menyebabkan adanya suatu pola luka yang berbeda-beda. Dengan distribusi korban kecelakaan lalu lintas terutama kelompok usia produktif dan lebih didominasi kaum laki-laki. Penelitian ini bertujuan untuk mengetahui bagaimana pola luka pada kasus kecelakaan lalu lintas yang masuk di Bagian Ilmu Kedokteran Forensik dan Medikolegal BLU RSU Prof. Dr. R. D. Kandou Manado periode 2010-2011. Penelitian ini bersifat retrospektif deskriptif. Pada hasil penelitian didapatkan bahwa dari tahun 2010 sampai tahun 2011 terjadi peningkatan kasus kematian karena kecelakaan lalu lintas. Jenis kelamin didominasi oleh laki-laki, dengan umur terbanyak pada interval 11-20 tahun dan 21-30 tahun. Jumlah luka terbanyak yang ditemukan adalah luka lecet, dengan lokasi luka tersering yaitu pada bagian kepala dan leher. Jenis kecelakaan terbanyak ditemukan pada pengemudi sepeda motor.

Kata Kunci: Pola luka pada kecelakaan lalu lintas. 
Kecelakaan lalu lintas sampai saat ini masih merupakan salah satu masalah kesehatan masyarakat di seluruh dunia. Dalam Global Status report on Road Safety-Time for Action, Organisasi Kesehatan Dunia (WHO) telah mempublikasikan bahwa kematian akibat kecelakaan di jalan diperlakukan sebagai salah satu penyakit tidak menular dengan jumlah kematian tertinggi. WHO melaporkan pada tahun 2009 dari kajian di 178 negara, setiap tahun sekitar 1,3 juta orang meninggal dunia akibat kecelakaan lalu lintas dan 20-50 juta jiwa menderita luka/cacat dimana 90\% terjadi di negaranegara berkembang termasuk Indonesia. Sejak tahun 2004-2009 dilaporkan jumlah kematian akibat kecelakaan lalu lintas tidak terjadi penurunan yang signifikan. Pejalan kaki, pengemudi sepeda, dan pengemudi sepeda motor merupakan kelompok terbesar yang menjadi korban, jumlahnya hampir separuh dari total korban. ${ }^{1}$

Jumlah kasus kecelakaan lalu lintas dari tahun ke tahun terus meningkat. ${ }^{2}$ Menurut data Badan Pusat Statistik Republik Indonesia, pada tahun 2008 jumlah kasus kecelakaan lalu lintas terdapat 59.164 kasus, kemudian meningkat di tahun 2009 dengan jumlah 62.960 kasus, dan terus meningkat di tahun 2010 dengan jumlah 66.488 kasus kecelakaan lalu lintas. ${ }^{3} \mathrm{Hal}$ ini disebabkan oleh ketidakseimbangan antara pertambahan jumlah kendaraan (14-15\% per tahun) dengan pertambahan prasarana jalan hanya sebesar $4 \%$ per tahun. ${ }^{2}$

Lebih dari $80 \%$ pasien yang masuk ke ruang gawat darurat adalah disebabkan oleh kecelakaan lalu lintas, berupa tabrakan sepeda motor, mobil, sepeda, dan penyebrang jalan yang ditabrak. Sisanya merupakan kecelakaan yang disebabkan oleh jatuh dari ketinggian, tertimpa benda, olahraga, dan korban kekerasan. ${ }^{4}$ Kematian akibat cedera diproyeksikan meningkat dari 5,1 juta menjadi 8,4 juta $(9,2 \%$ dari kematian secara keseluruhan) dan diestimasikan menempati peringkat ketiga disability adjusted life years (DALYs) pada tahun 2020. Masalah cedera memberikan kontribusi pada kematian sebesar 15\%, beban penyakit 25\% dan kerugian ekonomi $5 \%$ growth development product (GDP). ${ }^{5}$

Pada kecelakaan kendaraan motor, korban selalu terlempar dari kendaraannya, 19 sedangkan pada kecelakaan kendaraan mobil, bahaya terbesar saat pengendara terlempar ke luar dari kaca depan, sehingga cedera pada pengguna kendaraan bermotor dapat mengenai semua anggota tubuh khususnya kepala, ekstremitas atas dan bawah, dada dan abdomen. Hal tersebut menyebabkan adanya suatu pola luka yang berbeda-beda setiap kasus kecelakaan lalu lintas. Selain itu juga kecelakaan ini mempunyai lokasi yang beraneka ragam sesuai dengan keadaan dari lingkungan saat kecelakaan tersebut berlangsung. ${ }^{12}$ Tiap korban dan luka yang dideritanya merupakan perluasan dari tempat kejadian. Luka merupakan hal yang sangat umum terjadi dan merupakan bagian dari kehidupan sehari-hari, mulai dari kecelakaan, tusukan, goresan dan memar sampai patah tulang. Disadari juga bahwa kejadian kecelakaan lalu lintas mengakibatkan jenis perlukaan yang banyak sekali, ${ }^{6}$ dengan distribusi korban kecelakaan lalu lintas terutama kelompok usia produktif antara 15-44 tahun dan lebih didominasi kaum laki-laki. Kelompok ini merupakan aset sumber daya manusia yang sangat penting untuk pembangunan bangsa .

Berdasarkan uraian di atas, maka penulis tertarik untuk membuat penelitian mengenai pola luka yang berhubungan dengan kasus kecelakaan lalu lintas.

Berdasarkan rumusan masalah diatas maka tujuan yang akan dicapai: Tujuan umum untuk mengetahui bagaimana pola luka pada kasus kecelakaan lalu lintas yang masuk di Bagian Ilmu Kedokteran Forensik dan Medikolegal BLU RSU Prof. Dr. R. D. Kandou Manado periode 2010-2011. Tujuan khusus untuk mengetahui bagaimana karakteristik sosiodemografi korban kecelakaan lalu lintas (umur dan jenis kelamin) yang masuk di Bagian Ilmu Kedokteran Forensik dan Medikolegal BLU RSU Prof. Dr. R. D. Kandou Manado periode 2010-2011. Untuk mengetahui jenis 
luka pada korban kecelakaan lalu lintas yang masuk di Bagian Ilmu Kedokteran Forensik dan Medikolegal BLU RSU Prof. Dr. R. D. Kandou Manado periode 20102011. Untuk mengetahui jenis kecelakaan lalu lintas apa yang dialami korban kecelakaan lalu lintas yang masuk di Bagian Ilmu Kedokteran Forensik dan Medikolegal BLU RSU Prof. Dr. R. D. Kandou Manado periode 2010-2011.

\section{METODOLOGI PENELITIAN}

Jenis peneletian ini menggunakan desain retrospektif deskriptif. Penelitian ini dilakukan pada bulan September 2012Januari 2013. Penelitian ini menggunakan data sekunder yaitu, data yang diperoleh secara tidak langsung yang berasal dari Visum et Repertum (VER) korban kecelakaan lalu lintas. Populasi adalah korban kecelakaan lalu lintas yang masuk di Bagian Ilmu Kedokteran Forensik dan Medikolegal BLU RSU Prof. Dr. R. D. Kandou Manado. Sampel penelitian adalah korban kasus kecelakaan lalu lintas yang masuk di Bagian Ilmu Kedokteran Forensik dan Medikolegal BLU RSU Prof. Dr. R. D. Kandou Manado periode tahun 2010-2011 yang memenuhi kriteria inklusi dan eksklusi. Kriteria inklusi, yaitu semua jenis kecelakaan lalu lintas dan semua jenis cedera pada korban meninggal kecelakaan lalu lintas. Kriteria eksklusi, yaitu korban yang datanya tidak lengkap. Variabel penelitian yaitu karakteristik korban kecelakaan lalu lintas (umur dan jenis kelamin), pola luka pada korban kecelakaan lalu lintas, dan jenis kecelakaan lalu lintas. Definisi operasional yaitu karakteristik korban kecelakaan lalu lintas yang dimaksud adalah umur dan jenis kelamin korban sesuai dengan yang tercatat dalam
VER, umur adalah umur korban kecelakaan lalu lintas sesuai dengan yang tercatat dalam VER. Interval umur dibagi dalam 1-10 tahun, 11-20 tahun, 21-30 tahun, 31-40 tahun, 41-50 tahun, 51-60 tahun, 61-70 tahun, $\geq 70$ tahun, jenis kelamin dinyatakan dalam laki-laki dan perempuan. Luka adalah hilang atau rusaknya sebagian jaringan tubuh yang disebabkan oleh trauma benda tajam atau tumpul, perubahan suhu, zat kimia, ledakan, sengatan listrik atau gigitan hewan, pola luka yang dimaksud adalah gambaran bentuk luka sesuai yang ditemukan pada data korban kecelakaan lalu lintas, yaitu luka memar, luka robek, luka lecet, luka bakar, luka tembus. Pada penghitungan jumlah luka dilakukan sesuai dengan jumlah luka yang ditemukan, termasuk pada regio dan sisi tubuh yang berbeda (kiri dan kanan) karena pengelompokkan hanya dibagi berdasarkan lokasi luka pada tubuh, yaitu kepala dan leher, bahu dan dada, perut, punggung, pinggang dan bokong, tungkai atas, dan tungkai bawah. Jenis kecelakaan lalu lintas yang dimaksud adalah jenis kecelakaan yang dialami korban sesuai dengan yang tercatat dalam VER. Jenis kecelakaan dibagi menjadi pengemudi/pengendara sepeda motor, yang dibonceng di sepeda motor, penumpang mobil, dan pejalan kaki. Pengolahan data semua data yang diperoleh, diolah secara manual dan disajikan dalam bentuk tabel distribusi frekuensi.

\section{HASIL PENELITIAN}

Berdasarkan hasil pengumpulan data dari kasus kecelakaan lalu lintas yang masuk di Bagian Ilmu Kedokteran Forensik dan Medikolegal BLU RSU Prof. Dr. R. D. Kandou Manado periode 2010-2011 dapat dilihat pada tabel-tabel di bawah ini: 
Tabel 1. Jumlah kasus kecelakaan lalu lintas di tahun 2010-2011 secara keseluruhan dan yang memenuhi kriteria inklusi dan eksklusi

\begin{tabular}{lccc}
\hline $\begin{array}{l}\text { Kasus Kecelakaan } \\
\text { Lalu Lintas }\end{array}$ & $\mathbf{2 0 1 0}$ & $\mathbf{2 0 1 1}$ & $\begin{array}{c}\text { Total dan } \\
\text { persentase (\%) }\end{array}$ \\
\hline $\begin{array}{l}\text { Jumlah kasus } \\
\text { keseluruhan }\end{array}$ & $82(42,93 \%)$ & $99(54,69 \%)$ & $181(100 \%)$ \\
$\begin{array}{l}\text { Kasus dengan } \\
\text { kriteria inklusi }\end{array}$ & $32(40 \%)$ & $48(60 \%)$ & $80(100 \%)$ \\
$\begin{array}{l}\text { Kasus dengan } \\
\text { kriteria eksklusi }\end{array}$ & $50(49,51 \%)$ & $51(50,49 \%)$ & $101(100 \%)$
\end{tabular}

Keterangan : Warna biru = persentase jumlah kasus secara keseluruhan. Warna merah = pesrsentase jumlah kasus yang digunakan (kriteria inklusi). Warna ungu = persentase jumlah kasus yang tidak digunakan (kriteria eksklusi).

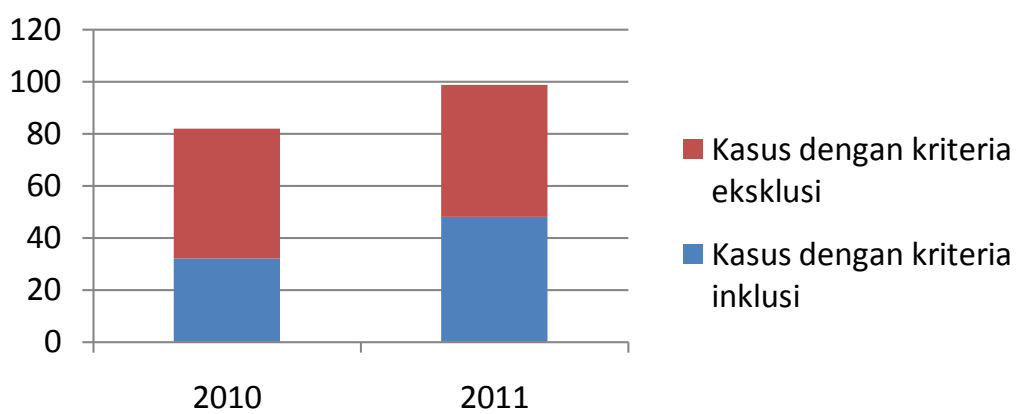

Gambar 1. Gambar perbandingan jumlah kasus kecelakaan lalu lintas dari tahun 2010 sampai tahun 2011 secara keseluruhan dan yang memenuhi kriteria inklusi eksklusi

Tabel 2. Distribusi korban kecelakaan lalu lintas berdasarkan jenis kelamin

\begin{tabular}{lccc}
\hline Jenis Kelamin & Tahun 2010 & Tahun 2011 & $\begin{array}{c}\text { Total dan persentase } \\
(\mathbf{\%})\end{array}$ \\
\hline Laki-laki & 24 & 43 & $67(83,75 \%)$ \\
Perempuan & 8 & 5 & $13(16,25 \%)$ \\
\hline Total (\%) & 32 & 48 & $80(100 \%)$ \\
\hline
\end{tabular}

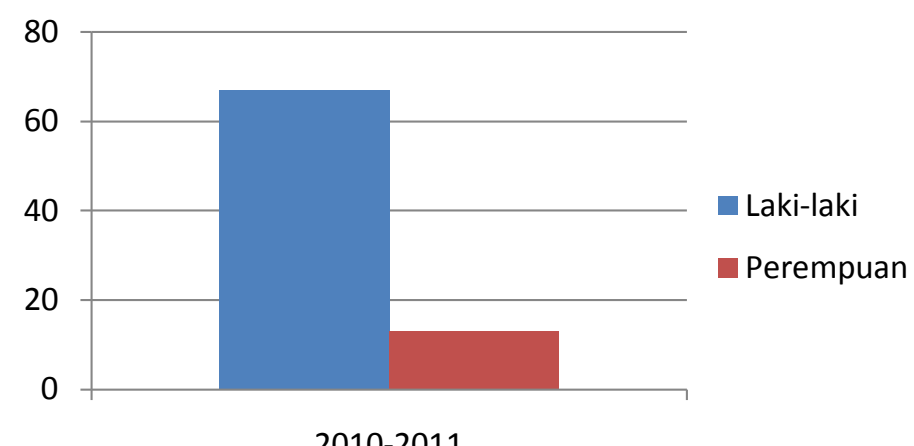

Gambar 2. Distribusi korban kecelakaan lalu lintas berdasarkan jenis kelamin di tahun 2010-2011 
680 Jurnal e-Biomedik (eBM), Volume 1, Nomor 1, Maret 2013, hlm. 676-685

Tabel 3. Distribusi korban kecelakaan lalu lintas berdasarkan umur

\begin{tabular}{lccc}
\hline $\begin{array}{l}\text { INTERVAL } \\
\text { UMUR }\end{array}$ & $\mathbf{2 0 1 0}$ & $\mathbf{2 0 1 1}$ & $\begin{array}{c}\text { Total dan } \\
\text { persentase (\%) }\end{array}$ \\
\hline 0-10 tahun & 1 & 0 & $1(1,25 \%)$ \\
11-20 tahun & 8 & 13 & $21(26,25 \%)$ \\
21-30 tahun & 4 & 16 & $20(25 \%)$ \\
31-40 tahun & 5 & 7 & $12(15 \%)$ \\
41-50 tahun & 6 & 6 & $12(15 \%)$ \\
51-60 tahun & 3 & 3 & $6(7,5 \%)$ \\
61-70 tahun & 4 & 1 & $5(6,25 \%)$ \\
$\geq 70$ tahun & 1 & 2 & $3(3,75 \%)$ \\
\hline Jumlah & $\mathbf{3 2}$ & $\mathbf{4 8}$ & $\mathbf{8 0}(\mathbf{1 0 0} \%)$ \\
\hline
\end{tabular}

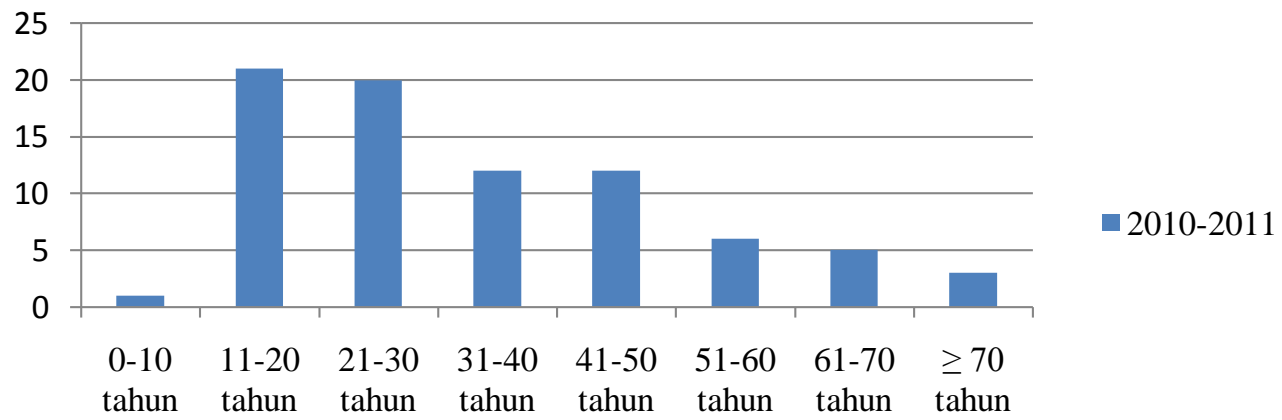

Gambar 3. Distribusi korban kecelakaan lalu lintas berdasarkan umur di tahun 2010-2011

Tabel 4. Distribusi pola luka korban kecelakaan lalu lintas berdasarkan lokasi luka pada tahun 2010

\begin{tabular}{lccccc}
\hline $\begin{array}{l}\text { Berdasarkan Lokasi } \\
\text { Tubuh }\end{array}$ & Luka Memar & Luka Robek & Luka Lecet & $\begin{array}{c}\text { Luka } \\
\text { Bakar }\end{array}$ & Total \\
\hline Kepala dan leher & $27(45 \%)$ & $20(52.63 \%)$ & $32(27,12 \%)$ & $0(0 \%)$ & 79 \\
Bahu dan dada & $8(13,33 \%)$ & $1(2,63 \%)$ & $9(7,65 \%)$ & $0(0 \%)$ & 18 \\
Perut & $2(3,33 \%)$ & $0(0 \%)$ & $3(2,54 \%)$ & $0(0 \%)$ & 5 \\
Bahu dan dada & $8(13,33 \%)$ & $1(2,63 \%)$ & $9(7,65 \%)$ & $0(0 \%)$ & 18 \\
Perut & $2(3,33 \%)$ & $0(0 \%)$ & $3(2,54 \%)$ & $0(0 \%)$ & 5 \\
Punggung & $3(5 \%)$ & $0(0 \%)$ & $6(5,08 \%)$ & $0(0 \%)$ & 9 \\
Pinggang dan bokong & $1(1,67 \%)$ & $2(5,27 \%)$ & $2(1,7 \%)$ & $0(0 \%)$ & 5 \\
Tungkai atas & $12(20 \%)$ & $8(21,05 \%)$ & $33(27,96 \%)$ & $0(0 \%)$ & 53 \\
Tungkai bawah & $7(11,67 \%)$ & $7(18,42 \%)$ & $33(27,96 \%)$ & $1(100 \%)$ & 47 \\
\hline Total (\%) & $60(100 \%)$ & $38(100 \%)$ & $118(100 \%)$ & $1(100 \%)$ & 216 \\
\hline
\end{tabular}

Keterangan: Warna ungu $=$ persentase jumlah luka memar berdasarkan lokasi pada tubuh. Warna biru= persentase jumlah luka robek berdasarkan lokasi pada tubuh. Warna merah= persentase jumlah luka lecet berdasarkan lokasi pada tubuh. Warna hijau= persentase jumlah luka bakar berdasarkan lokasi pada tubuh. 


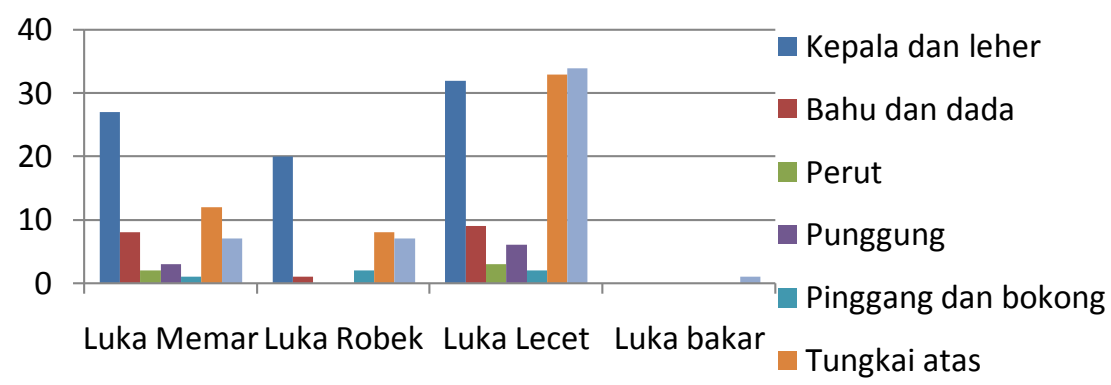

Gambar 4. Distribusi pola luka korban kecelakaan lalu lintas berdasarkan lokasi luka di tahun 2010

Tabel 5. Distribusi pola luka korban kecelakaan lalu lintas berdasarkan lokasi luka pada tahun 2011

\begin{tabular}{lccccc}
\hline $\begin{array}{l}\text { Berdasarkan } \\
\text { Lokasi Tubuh }\end{array}$ & Luka Memar & Luka Robek & Luka Lecet & $\begin{array}{c}\text { Luka } \\
\text { Tembus }\end{array}$ & Total \\
\hline $\begin{array}{l}\text { Kepala dan } \\
\text { leher }\end{array}$ & $52(53,61 \%)$ & $30(54,54 \%)$ & $47(25,97 \%)$ & $\begin{array}{c}1 \\
(100 \%)\end{array}$ & 129 \\
Bahu dan dada & $10(10,31 \%)$ & $1(1,82 \%)$ & $22(12,15 \%)$ & $0(0 \%)$ & 33 \\
Perut & $10(10,31 \%)$ & $0(0 \%)$ & $7(3,87 \%)$ & $0(0 \%)$ & 17 \\
Punggung & $1(1,03 \%)$ & $0(0 \%)$ & $4(2,21 \%)$ & $0(0 \%)$ & 5 \\
Pinggang dan & $0(0 \%)$ & $1(1,82 \%)$ & $4(2,21 \%)$ & $0(0 \%)$ & 5 \\
bokong & & & & & 66 \\
Tungkai atas & $17(17,52 \%)$ & $4(7,27 \%)$ & $45(24,87 \%)$ & $0(0 \%)$ & 66 \\
Tungkai bawah & $7(7,22 \%)$ & $19(34,55 \%)$ & $52(28,72 \%)$ & $0(0 \%)$ & 78 \\
\hline Total (\%) & $\mathbf{9 7 ( 1 0 0 \% )}$ & $\mathbf{5 5 ( 1 0 0 \% )}$ & $\mathbf{1 8 1}(\mathbf{1 0 0} \%)$ & $\mathbf{1 ( 1 0 0 \% )}$ & $\mathbf{3 3 3}$
\end{tabular}

Ket: Warna ungu $=$ persentase jumlah luka memar berdasarkan lokasi pada tubuh. Warna biru $=$ persentase jumlah luka robek berdasarkan lokasi pada tubuh. Warna merah = persentase jumlah luka lecet berdasarkan lokasi pada tubuh. Warna hijau = persentase jumlah luka tembus berdasarkan lokasi pada tubuh.

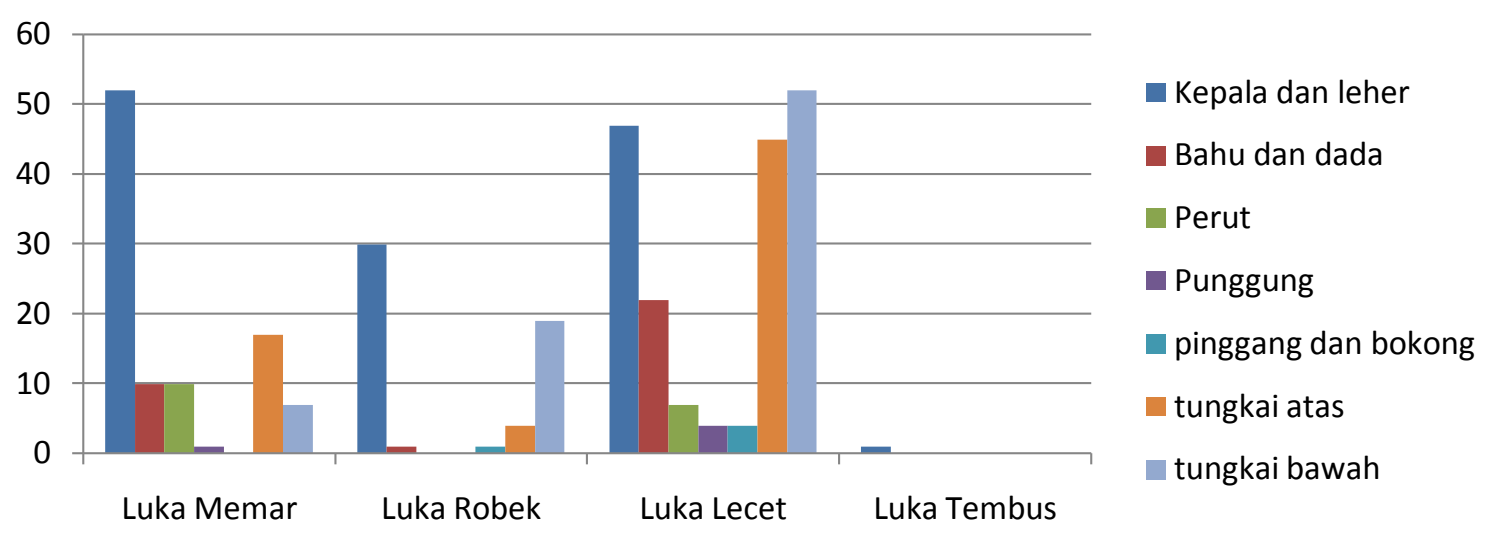

Gambar 5. Distribusi pola luka korban kecelakaan lalu lintas berdasarkan lokasi luka pada tahun 2011. 
682 Jurnal e-Biomedik (eBM), Volume 1, Nomor 1, Maret 2013, hlm. 676-685

Tabel 6. Perbandingan pola luka pada korban kecelakaan lalu lintas di tahun 2010 dan 2011

\begin{tabular}{lccc}
\hline Jenis Luka & $\mathbf{2 0 1 0}$ & $\mathbf{2 0 1 1}$ & Total dan \\
\hline Luka memar & 60 & 97 & $157(28,54 \%)$ \\
Luka robek & 38 & 55 & $93(16,90 \%)$ \\
Luka lecet & 118 & 181 & $299(54,36 \%)$ \\
Luka bakar & 1 & 0 & $1(0,18 \%)$ \\
Luka tembus & 0 & 1 & $1(0,18 \%)$ \\
\hline Total & $\mathbf{2 1 7}$ & $\mathbf{3 3 4}$ & $\mathbf{5 5 0}(\mathbf{1 0 0} \%)$ \\
\hline
\end{tabular}

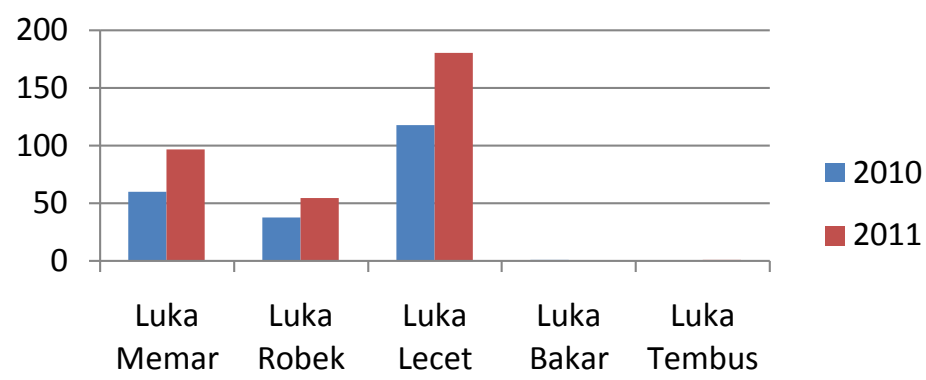

Gambar 6. Distribusi perbandingan pola luka korban kecelakaan lalu lintas berdasarkan umur di tahun 2010 dan 2011

Tabel 7. Distribusi data korban kecelakaan lalu lintas berdasarkan jenis kecelakaan lalu lintas

\begin{tabular}{lccc}
\hline Jenis Kecelakaan & $\mathbf{2 0 1 0}$ & $\mathbf{2 0 1 1}$ & Total dan \\
\hline Pengemudi sepeda motor & 19 & 34 & $53(66,25 \%)$ \\
Penumpang sepeda motor & 2 & 8 & $10(12,5 \%)$ \\
Penumpang mobil & 1 & 0 & $1(1,25 \%)$ \\
Pejalan kaki & 10 & 6 & $16(20 \%)$ \\
\hline Total & $\mathbf{3 2}$ & $\mathbf{4 8}$ & $\mathbf{8 0}(\mathbf{1 0 0} \%)$ \\
\hline
\end{tabular}

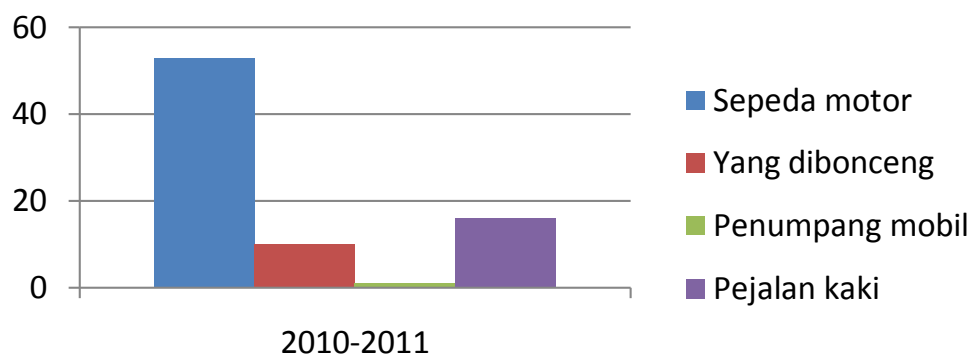

Gambar 10. Distribusi data korban kecelakaan lalu lintas berdasarkan jenis kecelakaan lalu lintas di tahun 2010-2011

\section{PEMBAHASAN}

Berdasarkan data hasil penelitian retrospektif deskriptif pada kasus kecelakaan lalu lintas yang masuk di Bagian Ilmu Kedokteran Forensik dan Medikolegal
BLU RSU Prof. Dr. R. D. Kandou Manado periode 2010-2011 jumlah keseluruhan kasus yang diperoleh adalah sebanyak 181 kasus kecelakaan lalu lintas, yaitu di tahun 2010 berjumlah 82 kasus dan di tahun 2011 
berjumlah 99 kasus. Dari data tersebut dapat diketahui bahwa di BLU RSU Prof. DR. R. D. Kandou dari tahun 2010 sampai tahun 2011 terjadi peningkatan kasus kematian karena kecelakaan lalu lintas sebanyak 17 kasus (9,4 \%). Jumlah keseluruhan kasus kecelakaan lalu lintas di tahun 2010-2011 yang berjumlah 181 kasus tersebut, hanya terdiri dari 80 kasus yang datanya memenuhi kriteria inklusi dan eksklusi, yaitu di tahun 2010 terdiri dari 32 kasus dan di tahun 2011 terdiri dari 48 kasus yang dapat dilihat pada tabel 1. Angka ini terus meningkat dari tahun ke tahun karena bisa dipengaruhi oleh beberapa faktor seperti : faktor kelalaian manusia itu sendiri, faktor kendaraan, faktor jalan, maupun faktor lingkungan. ${ }^{9}$

Data pada tabel 2 menunjukkan bahwa jumlah karakteristik korban kecelakaan lalu lintas dari tahun 2010 sampai tahun 2011 dengan jenis kelamin laki-laki mengalami peningkatan, yaitu di tahun 2010 berjumlah 24 korban (75\%) kemudian meningkat di tahun 2011 berjumlah 43 korban (89,59\%), terjadi peningkatan sebesar $14,59 \%$. Jumlah karakteristik korban kecelakaan lalu lintas dengan jenis kelamin perempuan di tahun 2010 dengan jumlah 8 korban (25\%) mengalami penurunan di tahun 2011 yaitu dengan jumlah 5 korban (10,41\%), terjadi penurunan $14,59 \%$. Dapat dilihat juga bahwa dari tahun 2010 sampai 2011 jumlah korban kecelakaan lalu lintas dengan jenis kelamin laki-laki berjumlah 67 korban $(83,75 \%)$ dan jenis kelamin perempuan berjumlah 13 korban (16,25\%). Jadi, dapat disimpulkan bahwa korban kecelakaan lalu lintas berdasarkan jenis kelamin dari tahun 2010 sampai tahun 2011, didominasi oleh laki-laki dengan rasio perbandingan laki-laki dan perempuan berkisar 5,1:1. Penelitian ini serupa dengan penelitian Metta Kartika di Jakarta pada tahun 2008, tercatat bahwa korban kecelakaan lalu lintas dengan jenis kelamin laki-laki lebih banyak dibandingkan dengan jenis kelamin perempuan. ${ }^{8}$ Hal ini mungkin dikarenakan laki-laki lebih sering mengemudikan kendaraan dengan kecepatan yang tinggi dibandingkan perempuan sehingga mempunyai risiko lebih tinggi mengalami kecelakaan. ${ }^{5}$

Pada tabel 3 menunjukkan data korban kecelakaan lalu lintas berdasarkan umur bahwa di tahun 2010 kasus terbanyak ditemukan pada interval umur 11-20 tahun sebanyak 8 kasus (25\%), sedangkan di tahun 2011 jumlah terbanyak ditemukan pada interval umur 21-30 tahun sebanyak 16 kasus (33,33\%). Setelah dijumlahkan total korban kecelakaan lalu lintas berdasarkan umur dari tahun 2010 sampai 2011, maka didapati umur terbanyak pada interval 11-20 tahun ditemukan sejumlah 21 kasus (26,25\%), yaitu di tahun 2010 terdiri dari 8 kasus (25\%) dan di tahun 2011 terdiri dari 13 korban (27,1\%). Jika dijumlahkan dan dikelompokkan berdasarkan usia produktif, maka angka kematian yang tinggi pada kelompok usia produktif akan jauh lebih tinggi dibandingkan kelompok umur lain. Hal ini dikarenakan kelompok usia produktif mempunyai mobilitas yang lebih tinggi dibandingkan dengan kelompok umur lain. ${ }^{5}$ Penelitian ini serupa dengan penelitian Arief Nugraha di Jakarta pada tahun 2011 . $^{6}$

Pada tabel 4 dan 5 menunjukkan pola luka yang hampir sama pada korban kecelakaan lalu lintas berdasarkan lokasi luka di tubuh, yaitu pada tahun 2010 jenis luka terbanyak yang ditemukan adalah luka lecet sebanyak 118 luka dan juga luka lecet di tahun 2011 sebanyak 181 luka. Dengan lokasi luka tersering yaitu ditemukan pada bagian kepala dan leher. Hasil penelitian di rumah sakit 5 provinsi di Indonesia juga menunjukkan bahwa bagian tubuh yang cedera paling banyak di bagian kepala, kemudian kaki dan tangan. Pola ini hampir sama yang terjadi di India terbanyak luka lecet $(47,4 \%)$ tapi terdapat pada bagian ekstremitas (62,2\%). ${ }^{5}$

Pada tabel 6 menunjukkan perbandingan pola luka pada korban kecelakaan lalu lintas di tahun 2010 dan 2011. Dengan meningkatnya kasus kecelakaan lalu lintas dari tahun 2010 sampai tahun 2011, jumlah pola luka juga mengalami peningkatan yaitu luka memar di tahun 2010 berjumlah 60 luka kemudian meningkat di tahun 2011 
berjumlah 97 luka, luka robek di tahun 2010 berjumlah 38 luka kemudian meningkat di tahun 2011 berjumlah 55 luka, dan luka lecet di tahun 2010 berjumlah 118 luka kemudian meningkat di tahun 2011 berjumlah 181 luka. Jadi jumlah luka terbanyak dari tahun 2010 sampai 2011 adalah luka lecet dengan jumlah 299 luka.

Pada tabel 7 menunjukkan data korban kecelakaan lalu lintas berdasarkan jenis kecelakaan lalu lintas terbanyak dari tahun 2010 sampai 2011 yaitu pengemudi sepeda motor dengan jumlah 53 kasus (66,25\%), kemudian oleh pejalan kaki (20\%), yang dibonceng $(12,25 \%)$, dan yang paling sedikit penumpang mobil (1,25\%). Penelitian ini serupa dengan penelitian M.K. Sinaga di Medan pada tahun 2010. ${ }^{1}$ Hal ini bisa saja dikarenakan pengemudi tidak menggunakan helm berstandart (pengendara motor), tidak memasang sabuk pengaman (pengendara mobil), tidak mematuhi rambu lalu lintas, ugal-ugalan, menggunakan ponsel saat berkendara, mengantuk, miras, dsb.

\section{SIMPULAN}

Berdasarkan data hasil penelitian, maka dapat disimpulkan bahwa jumlah keseluruhan kasus kecelakaan lalu lintas yang masuk di Bagian Ilmu Kedokteran Forensik dan Medikolegal BL U RSU Prof. Dr. R. D. Kandou Manado periode 2010-2011 adalah sebanyak 181 kasus dengan jumlah sampel yang digunakan sebanyak 80 kasus, yang mengalami peningkatan sebesar 9,4\%. Pola luka pada kasus kecelakaan lalu lintas berdasarkan umur, ditemukan jumlah luka terbanyak adalah luka lecet sebanyak 299 luka. Dengan bagian kepala dan leher sebagai lokasi cedera tersering. Hasil penelitian di rumah sakit 5 provinsi di Indonesia juga menunjukkan bahwa bagian tubuh yang cedera paling banyak di bagian kepala, kemudian kaki dan tangan. Karakteristik korban kecelakaan lalu lintas berdasarkan jenis kelamin yang ditemukan didominasi oleh laki-laki dengan rasio perbandingan laki-laki dan perempuan berkisar 5,1:1. Karakteristik korban kecelakaan lalu lintas berdasarkan umur, didapati interval umur terbanyak pada 11-20 tahun sebanyak 21 kasus (26,25\%). Jika dijumlahkan dan dikelompokkan berdasarkan usia produktif, maka angka kematian yang tinggi pada kelompok usia produktif akan jauh lebih tinggi dibandingkan kelompok umur lain. Hal ini bisa dikarenakan kelompok usia produktif mempunyai mobilitas yang lebih tinggi dibandingkan dengan kelompok umur lain. ${ }^{5}$ Jenis kecelakaan yang masuk di Bagian Ilmu Kedokteran Forensik dan Medikolegal BLU RSU Prof. Dr. R. D. Kandou Manado periode 2010-2011 yang terbanyak adalah pengemudi sepeda motor dengan dengan jumlah 53 kasus (66,25\%).

\section{SARAN}

Mengingat pentingnya keselamatan berkendaraan di jalan maka perlu diperhatikan bagi pengguna jalan untuk mematuhi rambu-rambu lalu lintas, menggunakan helm berstandart (pengendara motor), memakai sabuk pengaman (pengendara mobil), kecepatan berkendaraan dengan batas normal, tidak menggunakan ponsel saat berkendara, dsb. Mengingat data-data pasien yang kurang lengkap, maka untuk mempermudah penelitian selanjutnya, juga perlu dilakukan perbaikan pada penulisan Visum et Repertum (VER).

\section{UCAPAN TERIMA KASIH}

Terima kasih ditujukan kepada:

a. dr. Djemmy Ch. Tomuka, MH,SH,DFM sebagai Dosen Penguji I.

b. dr. L. Ratulangi Sp.F sebagai Dosen Penguji II.

c. Dr. dr. Erwin Kristanto sebagai Dosen Penguji III dan semua pihak yang secara langsung maupun tidak langsung yang telah memberikan ide/gagasan dalam penulisan skripsi ini.

\section{DAFTAR PUSTAKA}

1. Sinaga MK. 2008. Gambaran faktor-faktor penyebab kecelakaan lalu lintas di kota 
Medan tahun 2010. [Skripsi]. Fakultas Kesehatan Masyarakat Universitas Sumatera Utara, Medan.

2. Hardajati S. Penerapan variable traffic controllers system di DKI Jakarta. Disitasi pada tanggal 4 Februari 2008 dari: http://www.digilib.itb.ac.ai. [Last update : Agustus 2007]

3. BPS. 1992-2010. Statistik jumlah kecelakaan lalu lintas. Badan Pusat Statistik, Republik Indonesia.

4. Japardi I. Cedera kepala. Dalam : Patologi dan fisiologi cedera kepala. Jakarta : Bhuana ilmu popular. 2004.

5. Riyadina W, Suhardi, Permana M. 2009. Pola dan determinan sosiodemografi cedera akibat kecelakaan lalu lintas. 465. Vol 29. No.10. Pusat Penelitian Pengembangan Biomedis dan Farmasi, Badan Penelitian dan Pengembangan Kesehatan Departemen Kesehatan RI.
6. Nugraha A. 2007. Hubungan antara usia dan jenis kelamin dengan adanya luka memar pada kecelakaan lalu lintas di RS Bhayangkara tingkat I Raden Said Sukanto periode 2009-2010. h2. [Skripsi]. Fakultas Kedokteran Universitas Pembangunan Nasional"VETERAN",Jakarta

7. Saanin S. Cedera kepala. Disitasi pada tanggal 21 Maret 2008 dari http://www.angelfire.com/nc/neurosurgery/s ebab.html-19k. [Last update : Januari 2002].

8. Kartika M. 2008 . Analisis faktor penyebab kecelakaan lalu lintas pada pengendara sepeda motor di wilayah Depok. h47. [skripsi]. Fakultas Kesehatan Masyarakat Universitas Indonesia, Jakarta.

9. World Health Organization (WHO). Trafic Accidents. Disitasi pada tanggal 2 Juni 2008 dari http://www.who.int/world-healthday/previous/2004/infomaterials/world_repo rt/en/. [Last update : Januari 2007]. 